University of Colombo Review (Series III),

Vol. 1, No. 1, 2020

\title{
Protecting Human Rights in the Light of Industrial Water Pollution: Sri Lankan Law and Obligations under International Law
}

\section{Kokila Lankathilake Konasinghe ${ }^{1}$ \& Asanka Amitharansy Edirisinghe ${ }^{2}$}

1Senior Lecturer, Department of Public and International Law, University of Colombo

2Senior Lecturer, Department of Civil Law, General Sir John Kotelawala Defence University

\section{ABSTRACT}

The rapid decline of the natural environment, its resources, and habitats due to human activities has proven that environmental damage cannot be contained within territorial boundaries. Every State, region and continent is connected in the quest against environmental destruction and every nation has an obligation to ensure that activities within its territorial boundaries do not cause damage to the natural environment it shares with other States. Industrial water pollution has adversely affected the natural resources, environmental sustainability, and the lives of people in Sri Lanka in recent years. It violates the most crucial rights of people, depriving them of a clean and healthy environment, access to health, safe drinking water and even the right to life. In this context, it is important to ascertain the efficacy of the human rights guarantees available in Sri Lanka to fight against excessive levels of water pollution carried out for the sake of economic gain.

This article analyzes, therefore, the fundamental rights recognized by the Constitution of Sri Lanka against industrial water pollution. It seeks to ascertain whether fundamental rights guarantees against industrial water pollution in Sri Lanka are in line with internationally accepted human rights standards and emphasizes the necessity of addressing the silence in the Sri Lankan Constitution on the rights to life, environment, health, and water following internationally accepted human rights norms and practices.

\section{KEY WORDS:}

Industrial water pollution, right to life, right to environment, right to water, right to health, rights of nature

Suggested Citation: Konasinghe, K. L. \& Edirisinghe, A. A. (2020). Protecting human rights in the light of industrial water pollution: Sri Lankan law and obligations under international law. University of Colombo Review (Series III), $1(1), 60-80$.

(c) 2020 The Authors. This work is licenced under a Creative Commons Attribution 4.0 International Licence which permits unrestricted use, distribution, and reproduction in any medium, provided the original work is properly cited. 


\section{Introduction}

Environmental pollution and degradation of natural resources following the disposal of industrial wastewater has become a common phenomenon in contemporary Sri Lanka. The most crucial of these incidents include the water crisis in Rathupaswala in 2013 due to alleged ground water pollution by a rubber glove manufacturing company (Perera, 2015; Rodrigo, 2013), the contamination of the Kelani river in 2015 due to diesel oil spillage by a well-reputed, multi-national beverage company (Environmental Foundation Limited, 2015), well water pollution in the Chunnakam area in the Jaffna peninsula due to the operations of a thermal power station since 2009 (Jeevaratnam et al., 2018; Suntha, 2018; Vallipuranathan, 2015) and the chronic kidney disease in the dry zone of Sri Lanka often attributed to agricultural water pollution (Jayasumana et al., 2017; Kafle et al., 2019). These incidents have had long-lasting implications not only on environmental sustainability, but also on the most basic rights of the people affected.

According to Shelton (2010), human rights are maximum claims on society which elevate the necessity of safeguarding the environment and common citizenry against adverse wastewater management practices (including wastewater management) above being a mere policy choice that may be modified or discarded at will. Rights are inherent attributes of human beings that must be respected in any well-ordered society. The constitutional guarantees are at the apex of the hierarchy of legal norms and have the power to trump any conflicting norm of lower value (p. 266). As held in the case Premachandra v Major Montague Jayawickrema (1994), "in Sri Lanka, it is the Constitution which is supreme" (p. 111). Therefore, the fundamental rights guarantees stemming from the supreme law of the country form one of the strongest barriers against government actions or omissions that facilitate and encourage adverse industrial activities. In this context, it is necessary to analyze the human rights guarantees available against industrial water pollution under the domestic law of Sri Lanka.

Sri Lanka is interconnected with the global community in finding legal solutions for environmental issues like industrial water pollution due to two fundamental reasons. Firstly, industrial water pollution can carry transboundary environmental impacts which require a collective effort by different States to find solutions. Secondly, the Sri Lankan State has an obligation to ensure that internationally accepted human rights standards are available to its citizens at least as far as crucial issues like water pollution are concerned. In this context, it is essential to ensure that domestic legal interpretations of the human rights affected by industrial water pollution are linked to global developments concerning the same. Therefore, it is important to examine the compatibility of domestic human rights guarantees in Sri Lanka with international standards.

This article consists of eight parts. The first part discusses the international legal recognition of human rights affected by industrial water pollution. The second discusses the recognition of the concept of the rights of nature in international law and its implications in the protection of the environment against industrial water pollution. The third analyzes the recognition of the human rights affected by industrial water pollution in Sri Lanka. The fourth evaluates the ability to use the existing fundamental rights regime in Sri Lanka 
against industrial water pollution. The fifth examines Sri Lanka's human rights obligations under international law and the ability to expand the scope of the constitutionally recognized fundamental rights through the references made to international legal instruments. The sixth seeks to ascertain the implications of public interest litigation in strengthening the fight against industrial water pollution in Sri Lanka. The seventh lays down suggestions to reform the human rights regime in Sri Lanka to confer better protection on its citizens and the environment. The final part presents the conclusion of the article.

\section{International Recognition of Human Rights Affected by Industrial Water Pollution}

Throughout history, the scope of human rights has expanded gradually to encompass all human beings, regardless of race, ethnicity, gender, or social status (Donnelly, 2003). Consequently, the concept of human rights now goes beyond the narrow list of the rights to life, property, and liberty, to encompass a wide array of internationally recognized rights (Leib, 2011). The legal community even recognizes the need for expanding the scope of rights beyond human beings. According to Edmundson (2004):

the expression "human rights" suggests that there is some deep conceptual connection between belonging to the human species and having rights; perhaps it should be retired - just as the phrase "the rights of man" has given way to gender neutrality equivalents. (p. 186)

There are four basic human rights which are directly affected by the adverse impacts of industrial wastewater. These are the rights to life, environment, health, and water.

The first of these rights, the right to life, is considered the essence and life blood of all other types of rights, because one needs to be alive to enjoy any other right. According to Vasak (1982), the right to life is the first right of man. The right to life is recognized today as a non-derogable right and a peremptory norm in international law (Leib, 2011). The right to life is recognized by major international and regional human rights instruments including Article 3 of the Universal Declaration of Human Rights (UDHR) (1948), Article 6 of the International Covenant on Civil and Political Rights (ICCPR) (1966), Article 4 of the African Charter on Human and People's Rights (African Charter) (1981), Article 4 of the American Convention on Human Rights (ACHR) (1969), and Article 2 of the European Convention on Human Rights (European Convention) (1953).

The right to life imposes not only a negative obligation on State parties to refrain from infringing on this right, but also a positive duty to take appropriate actions to safeguard life. According to the General Comment 6 of the United Nations Human Rights Council (UNHRC), "[t]he right to life as a supreme and non-derogable human right should not be interpreted in a narrow way" (para 1). It further states, "[i]n this regard, states are urged to take positive measures in order to protect human life, including the reduction of infant mortality, increase in life expectancy, and eradication of malnutrition and epidemics" (para 5).

The broad interpretation of the right to life adopted in the comment imposes an obligation on State parties to eliminate any form of harm or damage which will adversely 
affect the environment and thereby deprive the people of their right to life. In the case Oneryildiz v Turkey (2004), it was accepted that the right to life guaranteed in international conventions not only imposes a negative obligation on State authorities to refrain from the arbitrary use of force, but also includes a positive obligation for States to take appropriate steps to safeguard the lives of those within their jurisdiction, which includes facilitating a healthy environment.

The most successful adoption of the right to life for the protection of the environment can be seen in Indian jurisdiction. In a series of judicial decisions, the Indian judiciary recognized that the right to a clean and healthy environment is inherent in the meaningful interpretation of the right to life recognized by Article 21 of the Indian Constitution (1950). These judicial decisions include, MC Mehta group of cases (1987a, 1987b, 1988a, 1988b), Chhetriya Pardushan Mukti Sangarsh Samati v State of Uttar Pradesh (1990), Subhash Kumar v State of Bihar (1991), MC Mehta v Kamal Nath (2000), Andra Pradesh Pollution Control Board v MV Nayadu (1999) and KM Chinnappa v Union of India (2003).

The case Indian Council for Enviro-legal Action v Union of India (Sludge Case) (1996) considered the possibility of applying the right to life provision in the Constitution directly against industrial water pollution. The case, considering the impact of highly toxic untreated wastewater on the environment and people, accepted that the discharge of untreated highly toxic effluents had caused enormous damage to the village. The court fixed the responsibility on the respondent industry to take effective remedial action, holding that when the industry is run with blatant disregard to the law to the detriment of the life and liberty of the citizens, it is self-evident that the court would intervene and protect the fundamental rights and liberties of the citizens.

The right to clean water and health are understood as elements of the right to life in India. In FK Hussain v Union of India, the court held that "the right to sweet water and the right to free air are attributes of the right to life for these are the basic elements which sustain life itself" (para 6). The same position was upheld by the Allahabad High Court in the subsequent case, SK Garg v State of Uttar Pradesh (1999), where the court held that the right to water is a part of the right to life guaranteed by Article 21. In Rural Litigation and Entitlement Kendra $v$ State of Uttar Pradesh (Dehradun Quarrying Case) (1985), the Supreme Court of India attempted to determine whether the right to life recognized by Article 21 could be extended to the right to health and other hygienic conditions. The court, in arriving at a decision, considered the hardship caused to the lessees, but was of the view that "it is a price that has to be paid for protecting and safeguarding the right of the people to live in a healthy environment with a minimal disturbance to ecological balance".

The second, the right to environment, has also been recognized in a number of international legal instruments today and is considered an effective instrument against corporate environmental damage when it is construed in a manner that prioritizes maximum protection of the well-being of humans and ecosystems (Mwanza, 2019). According to Principle 1 of the Stockholm Declaration (Declaration of the United Nations Conference on the Human Environment, 1972): 
Man has the fundamental right to freedom, equality and adequate conditions of life, in an environment of a quality that permits a life of dignity and well-being, and he bears a solemn responsibility to protect and improve the environment for present and future generations.

Resolution 45/94 of the UN General Assembly (1990) recalled the language of Stockholm, stating that "all individuals are entitled to live in an environment adequate for their health and well-being". According to Shelton, the resolution called for enhanced efforts towards ensuring a better and healthier environment (2002, p. 3).

However, this was not repeated in the 1992 Rio Declaration, which makes human beings "the central concern of sustainable development" and refers only to their being "entitled to a healthy and productive life in harmony with nature" (Boyle, 2006, p. 473). The failure of the Rio Declaration to give greater emphasis to environmental rights was indicative of uncertainty and debate about the proper place of human rights law in the development of international environmental law (Shelton, 1992, p. 82). However, the role of the Rio Declaration (1992) in influencing subsequent elaboration of a human right to environmental quality cannot be entirely disregarded. Moreover, the African Charter and Additional Protocol to the American Convention on Human Rights in the Area of Economic, Social and Cultural Rights directly guarantee a substantive right to environment. Furthermore, the right to environment has now spread all over the world and "continues to find homes in an ever-growing list of national Constitutions" (Gellers \& Jeffords, 2019, p. 190).

The third of these, the right to health, can also provide an efficient shield against negative implications of industrial water pollution and a successful substitution to the right to a clean and healthy environment. According to Shelton health is a subject that bridges the two fields of environmental protection and human rights ((2002), p. 3). There is no doubt that a clean and healthy environment is a pre-requisite for the achievement of human health and well-being. Therefore, the right to environment and right to health are inextricably and indivisibly linked. According to Van der Linde and Louw, it is not clear whether a claim to environmental protection can be successfully invoked without linking it to the right to health (2003, p. 176).

The right to health is recognized and embodied in many international human rights instruments. According to Article 11 of the International Covenant for Economic, Social and Cultural Rights (ICESCR), "the States Parties to the present Covenant recognize the right of everyone to the enjoyment of the highest attainable standard of physical and mental health". It further specifies that such States Parties shall improve all aspects of environmental and industrial hygiene in order to achieve full realization of the right to health. According to the General Comment No. 14, adopted by the Committee on Economic, Social and Cultural Rights (ESCR) in 2000, "The right to health embraces a wide range of socio-economic factors that promote conditions in which people can lead a healthy life and extends to the underlying determinates of health such as... a healthy environment" (para 4). This right is also recognized by Article 24 of the United Nations Convention on the Rights of the Child, Article 10 of the Protocol of San Salvador, and Article 16 of the African Charter. 
Moreover, international law now favours the recognition of a right to water, the fourth right under discussion. While this right has still not been recognized as a stand-alone human right in international conventions, the international community has acknowledged the significance of clean water and its vital role for the full realization of human rights. The concept of basic water requirements to meet fundamental human needs was first established at the 1977 UN Water Conference in Mar del Plata, Argentina (Falkenmark, 1977), and subsequently confirmed by Agenda 21 adopted at the UN Conference on Environment and Development in 1992.

The General Comment No. 15 adopted by the Committee on Economic, Social and Cultural Rights in 2002 laid down that, "the human right to water is indispensable for leading a life in human dignity. It is a prerequisite for the realization of other human rights" (para 1). The comment defined the right to water as "the right of everyone to sufficient, safe, acceptable and physically accessible and affordable water for personal and domestic uses" (para 2). According to the Special Rapporteur of the Sub-Commission on the Right to Drinking Water Supply and Sanitation, El Hadji Guissé, the right to water clearly falls within the category of guarantees essential for securing an adequate standard of living, particularly since it is one of the most fundamental conditions for survival. (Guissé, 2002, para 32).

In 2007, the High Commissioner for Human Rights stated that the time had come to consider the right to access safe drinking water as a human right (United Nations, 2010, p. 5). Resolution 64/292 adopted by the UN General Assembly in 2010, called upon States and international organizations to provide financial resources, and help capacity-building and technology transfer particularly so that developing countries can provide safe, clean, accessible, and affordable drinking water to their citizens.

The Berlin Rules on Water Resources in 2004 (International Law Association) which condenses the customary international law relating to the management of waters, recognizes the right of every individual to have access to sufficient, safe, acceptable, physically accessible, and affordable water to meet that individual's vital human needs. It further imposes a duty on State parties to refrain from interfering with the enjoyment of this right and to prevent third parties from doing the same. Thus, State parties have an obligation to refrain from water pollution while taking appropriate steps in preventing the pollution of water by others.

\section{Recognition of Rights of Nature in International Law}

Apart from the recognition of these salient human rights, one of the emerging trends in the world today is the recognition of independent and inherent rights of the environment through constitutional, legislative or judicial mechanisms. Chapter 7 of the Constitution of Ecuador enacted in the year 2008 recognizes rights of nature following the Andean belief of the divinity of mother earth or Pachamama. Bolivia absorbed rights of nature into its legislative framework through the Law of Mother Earth (Ley de Derechos de La Madre Tierra) in 2010 and, in 2012, the Framework Law of Mother Earth and Integral Development for Living Well (Ley Marco de la Madre Tierra y Desarrollo Integral para 
Vivir Bien) (Framework Law). New Zealand adopted the rights of nature through the Te Urewera Act in 2014 and Te Awa Tupua (Whanganui River Claims Settlement) Act of 2017. India adopted rights of nature through Mohd Salim v State of Uttarakhand and others (2017) and Lalit Miglani v State of Uttarakhand and others (2017) which recognized the Ganges and Yamuna rivers as legal persons. This recognition of the legal personhood of nature in India was, however, reversed by the subsequent Supreme Court decision which declared that the rivers are not legal persons (The State of Uttarakhand v Mohd Salim, 2018). The recognition of rights of nature places man in his rightful position as a part of the environment and recognizes that nature has rights and legal standing to fight for its own preservation against any form of pollution including those resultant from improper discharge of industrial wastewater. It allows all parties to bring claims for the preservation of lands and natural resources for "environmental or spiritual reasons or for no reason at all" (White, 2018, p. 131).

Moreover, according to contemporary interpretation, right to life in India is not merely anthropocentric. As pointed out by Leelakrishnan (2010):

It is likely that the fundamental right to environment set out through Article 21 may not be confined to human beings only. Environment, being a compendium of many things, one may reasonably argue that, for interpreting the expression 'person' in Article 21, as a non-human does have a legal personality. (p. 252)

This approach is clearly evident in the verdict of the Sludge Case (1996) which speaks on behalf of the environment, soil, trees and wells, and the damage caused to these environmental objects consequent to industrial water pollution.

It is clear from the above discussion that the international human rights framework is continuously and constantly evolving and expanding, recognizing novel rights and innovative avenues to confer better protection on human beings against environmental violations such as industrial water pollution, and safeguarding the inherent rights of water resources. Environmental issues arising out of industrial water pollution in Sri Lanka cannot be considered solely in domestic legal terms since environmental damages are of a transboundary nature. Decades of experience have proved that even the slightest environmental harm can carry wide-spread consequences in the long term which affect not only the people of one country, but also those living anywhere in the planet. The Earth is one single system, so the damage in one part of the world can affect all other countries. As the popular saying goes, "All things are connected like the blood that unites us all". In this context, it is salient to evaluate the domestic legal framework in Sri Lanka to ascertain whether the fundamental rights embodied in its law are in line with internationally accepted human rights yardsticks, because as far as nature is concerned, Sri Lanka is undoubtedly connected to the rest of the world.

\section{Recognition of Human Rights Affected by Industrial Water Pollution in Sri Lanka}

The Constitution of Sri Lanka (1978) does not confer a specific right on the community to have a clean and healthy environment and does not recognize rights to health or water. The situation is exacerbated by the silence of the Constitution of Sri Lanka with 
regard to the right to life. Although not expressly recognized by the Constitution, the right to life, as already established, is so fundamental that its absence makes all other rights entirely futile. Human life is undeniably sustained by a clean and healthy environment. In this context, fundamental rights to life and environment are particularly important in fighting against industrial water pollution because these two rights directly determine the continuous existence of human beings and therefore, clearly outweigh many rights concerning industrial activities including the right to economic development or occupation.

The judiciary in Sri Lanka recognized an implied right to life in the case Sriyani Silva v Iddamalgoda, OIC, Police Station Payagala and others (2003) by virtue of Articles 11, 13 (2), 13 (4) and 17 of the Constitution (1978). However, the judicial definition of right to life adopted in the case was extremely narrow and recognized the right of the people towards mere existence, not the quality of life. The same definition was adopted in the recent case, Rathnayake Tharanga Lakmali v Officer-in-Charge, Crime Branch, Embilipitiya Police Station and others (2019). This definition undoubtedly disregards the right of the people to live in a clean and healthy environment which facilitates dignity of human life. An environment related fundamental rights case that attempted to invoke the right to life directly, on the basis that such a right is implicitly recognized by the Constitution even if not expressly declared, was Deshan Harindra (a minor) v Ceylon Electricity Board (1998) which involved severe noise pollution from a diesel generator that was affecting very young children. As the case ended in a settlement, the legal argument on the right to life was not tested (Rajepakse, 2009).

At first glance, therefore, the fundamental rights jurisdiction that can be invoked against improper wastewater discharges by industries seems minimal. In this context, it is important to analyze the ability of the people of Sri Lanka to claim rights for environment, health or water, and the role played by the Sri Lankan judiciary in the creative and progressive interpretation of existing rights to confer a wider protection on the people against industrial water pollution.

Article 125 (1) and 126 of the Constitution (1978) confers upon the Supreme Court of Sri Lanka the power to have sole and exclusive jurisdiction to hear and determine any question relating to the interpretation of the Constitution and any infringement or imminent infringement of any fundamental right by executive or administrative action respectively. A careful analysis of the existing body of case laws makes it clear that by virtue of these articles, environmental protection and the right of the people towards a healthy environment have been implicitly recognized by the judiciary in Sri Lanka.

\section{The Use of Existing Fundamental Rights against Industrial Water Pollution in Sri Lanka}

The most frequently invoked Article against activities adversely affecting the environment and people is Article 12 of the Constitution (1978). Article 12 emphasizes that all persons are equal before the law and are entitled to the equal protection of the law and confers protection against discrimination. The basic premise for utilizing this equality clause against the negative effects of industrial and development activities on the environment and 
citizenry is that a failure to apply the existing laws of the country to a particular project or geographical area could amount to unequal treatment of those affected and thus constitute an infringement of Article 12 (Rajepakse, 2009).

This principle was applied in Bulankulama $v$ Secretary, Ministry of Industrial Development (Eppawela Case) (2000), where the petitioners were denied the right to participate in the Environmental Impact Assessment (EIA) process prescribed by the National Environmental Act because the project developer was to be allowed to do his own EIA through a foreign consultant of his choice. It was thereafter applied in a number of subsequent cases including Environmental Foundation Limited v Urban Development Authority (Galle Face Green Case) (2005), Al Haj MTM Ashik v RPS Bandula, OIC Weligama (the Noise Pollution Case) (2007), and Sugathapala Mendis v Chandrika Bandaranaike Kumaratunga (Waters Edge Case) (2008). As held by Tilakawardane J in Watte Gedara Wijebanda v Conservator General of Forest and eight others (Watte Gedara Wijebanda Case) (2007):

The right of all persons to the useful and proper use of the environment and the conservation thereof has been recognized universally and also under the national laws of Sri Lanka. While environmental rights are not specifically alluded to under the fundamental rights chapter of the Constitution, the right to a clean environment and the principle of inter-generational equity with respect to the protection and preservation of the environment are inherent in a meaningful reading of Article 12 (1) of the Constitution. (p. 356)

Article 12 can well be applied against industrial water pollution on a parity of reasoning. The application of the equality and non-discrimination clause to industrial wastewater management ensures that no person will bear an unequal burden of industrialization and upholds the fundamental principles of environmental justice.

The right to equality was also utilized by the judiciary in Sri Lanka to ensure access to clean and safe water. In Ravindra Gunawardena Kariyawasam v Central Environmental Authority and others (Chunnakam Power Plant Case) (2019), Jayawardena J recognized that the deprivation of clean water is a violation of the right to equality recognized by Article 12 of the Constitution (1978), holding that:

Access to clean water is a necessity of life and is inherent in Article 27 (2) (c) of the Constitution which declares that the State must ensure "the realization by all citizens of an adequate standard of living for themselves and their families, including adequate food, clothing and housing, the continuous improvement of living conditions and the full enjoyment of leisure and social and cultural opportunities". It is public knowledge that the majority of the people of our country have ready access to clean water which is provided by the apparatus of the State. It is also undisputed that prior to the pollution of groundwater in the Chunnakam area referred to earlier, the residents of that area had clean water. Thus, the pollution referred to earlier has deprived the residents of the Chunnakam area of access to clean water. They have, thereby, been placed at a significant disadvantage when compared to residents elsewhere in the country. (p. 53) 
While the right to clean water is not very elaborately and comprehensively described in the judgement, the recognition of deprivation of clean water as a violation of the right to equality is a remarkable step forward in environmental fundamental rights litigation in Sri Lanka. The judgment was delivered against ground water pollution by a thermal power plant situated in the Chunnakam area in the northern peninsula. It provided a perfect example of how the right to equality can be enforced against industries polluting water resources and towards safeguarding the basic need of water to all communities.

Secondly, Article 11 of the Constitution (1978) which emphasizes that no person shall be subjected to torture or to cruel, inhuman or degrading treatment or punishment, can also be raised against industrial water contamination. The judicial precedent in Sri Lanka holds that the application of the right extends not only to physical torture but also to mental torture (Adhikari and another $v$ Amarasinghe and others, 2002). Industrial water pollution adversely affects the ability of people to use clean water and thus inflicts a physical and mental torture upon them. Consequently, it violates the right of the affected people to be free from torture. An attempt to apply this right was evident in Environmental Foundation Limited v Attorney General (Nawimana Case) (1992) against quarry blasting operations. The case ended in a settlement, but the favourable attitude shown by the judiciary in this case points to how the judiciary will not be hesitant in applying the right against physical and psychological torture inflicted upon people by industrial water pollution.

Furthermore, Article 14 (1) (a) which ensures the entitlement of all citizens to the freedom of speech and expression including publication has been utilized in environmentrelated fundamental rights litigation. This right can bring about social and attitudinal change against industrial water pollution by influencing public opinion through persuasion. It can also protect all individual rights by ensuring that people speak their minds when their rights have been violated without fear of repercussions (Cooney et al., 2012). The power of this right has been particularly manifest in social media which serves as an outlet for the general public to express itself on contemporary social, legal and political issues, and against injustice. Freedom of publication, as Thomas Jefferson (1904 - 05) correctly commented, "is the best instrument for enlightening the mind of man and improving him as a rational, moral, and social being” (as quoted in Hachten, 2005, p. 30).

In the case Environmental Foundation Limited v Urban Development Authority (Galle Face Green Case) (2005) this right to freedom of speech has been progressively interpreted by the Supreme Court of Sri Lanka to include the right to secure relevant information from a public authority in respect of a matter that should be in the public domain. As held by Amerasinghe J. in the Eppawela Case, "access to information on environmental issues is of paramount importance" (2000, p. 316). Recently, the right to access information was expressly recognized by the 19th Amendment to the Constitution enacted in 2015, which, contrary to expectation, limited and circumscribed the right due to several reasons (Jayawickrama, 2016). Firstly, the exact scope of the fundamental right to information is set out in the Right to Information Act, No. 12 of 2016 and an individual is able to seek access to information under the act only to the extent it is allowed therein, not under the Constitution. Secondly, only a citizen may enjoy the right as opposed to all 
persons. Thirdly, the right can be restricted for a variety of reasons some of which can hardly be regarded as legitimate grounds to restrict access to information (p. 130-131).

In modern democracies, the right to information has emerged as a sine qua non of transparency and public participation, and a means of ensuring sustainable development (Wickramasinghe, 2015). As held in the case Gunaratne v Homagama Pradeshiya Sabha (1998), access to information is essential if sustainable development is to be achieved. The right to information ensures the openness of administrative activities and enables the general public to monitor administrative authorities and private industries. The right to information is therefore key to guaranteeing that industrial development in the country will be more people and environment centric and will not result in irreversible environmental destruction. Unfortunately, in Sri Lanka, the 19th Amendment to the Constitution and the introduction of a separate piece of legislation on access to information, though hailed as a salutary step towards sustainable development, has, in fact, shrunk the scope of this right.

The Constitution (1978) guarantees the right of every citizen the freedom to engage either individually, or in association with others, in any lawful occupation, profession, trade, business or enterprise. When it comes to industrial activities, this right can be utilized in two ways: to ensure continuous operation of industries as well as to protect someone's livelihood from getting affected by adverse industrial activities. An important limitation to the right was set in the case Jayawardena $v$ Akmeemana Pradeshiya Sabha and others (1997), where the court held that the right guaranteed by Article 14 (1) (g) does not extend to any occupation, profession, trade, business or enterprise which is unlawful according to the prevailing law of the country. This ensures that no citizen has the right to carry out an industrial activity as his/her livelihood if it conflicts with existing environment protection laws of the country or affects the rest of the community adversely.

The other significant right that can be utilized with regard to industrial water pollution is the right to movement guaranteed by Article 14 (h) of the Constitution (1978). The right was successfully applied and upheld in a number of landmark judicial decisions concerning environmental issues in Sri Lanka including the Eppawela Case (2000) and the Heather Therese Mundy v The Central Environmental Authority (2004) case.

The above discussion demonstrates that fundamental rights jurisdiction in Sri Lanka is not comprehensive and lacks the most crucial rights that can safeguard human beings against industrial water pollution. The judiciary has, nevertheless, taken a progressive approach in interpreting the existing fundamental rights, thus conferring the widest protection possible within the constitutional scope of fundamental rights. However, irrespective of these progressive judicial decisions and constitutional amendments, the fundamental rights in Sri Lanka still lags behind international standards in relation to the specific issue of industrial water pollution. Moreover, the silence on the part of the judiciary in recent years in progressively interpreting the rights of the people with regard to the environment questions the willingness of the judiciary to further the progressionist path set by its forerunners. This dormant period was, however, broken by the Chunnakam Power Plant Case decided in early 2019, which brings new hopes of the retrieval of the "green wave" across judicial decisions once again. 


\section{Sri Lanka's Human Rights Obligations under International Law}

In the absence of fundamental rights that can be directly enforced against industrial water pollution, it is important to analyze the ability of the people of Sri Lanka to expand their rights beyond the scope expressly enumerated in the Constitution. In this regard, referring to the rights recognized in international instruments, to which Sri Lanka is a party, gains importance.

According to the Constitution (1978), in the Republic of Sri Lanka, sovereignty is in the people and includes fundamental rights. In the view of Mark Fernando (2004):

Article 03 does not purport to vest sovereignty in the people or to confer rights on the people. Article 03, instead, proceeds on the basis that sovereignty is already (and independently of the Constitution) vested in the people: accordingly, the people already possess certain rights. Article 04 refers to a narrower category of fundamental rights which are declared and recognized by the Constitution. Nonetheless, the collective interpretation of Article 03 and 04 means that the people in Sri Lanka possess other rights besides those specifically enumerated in the Constitution which includes rights recognized in international legal instruments. (p. 294)

The Eppawela Case (2000) which held that international instruments can be regarded as soft law displayed an inclination towards monism. This view was approved by Shiranee Tilakawardane J. in Watte Gedara Wijebanda Case (2007) where it was held that "... although the international instruments ... are not legally binding upon governments, they constitute an important part of our environmental protection regime" (p. 338). There are also many other judicial decisions where the courts have used international standards to interpret both the Constitution and statutory provisions (Sirisena Cooray $v$ Tissa Bandaranayake, 1999; Weerawansa v Attorney General, 2000).

However, this progressive view was reversed in Nallaratnam Singarasa v Attorney General (Singarasa Case) (2006), where it was held that the rights recognized in international instruments are not rights under Sri Lankan law, unless they have been enacted or incorporated into the domestic legal framework. The Supreme Court of Sri Lanka erred in the Singarasa Case by not addressing the argument that human rights law deserves a special status in international law and by not upholding the customary international law principles embedded in the ICCPR (Dias \& Gamble, 2006). Irrespective of the academic criticisms of the decision, it still remains the authoritative judicial precedent governing the area. Therefore, according to the contemporary judicial stance, the human rights recognized in international law, including the right to environment, are inoperable in the domestic context of Sri Lanka in the absence of an enabling legislation. In this context, the ability of the judiciary to expand on constitutional rights using the rights recognized in international instruments signed and ratified by Sri Lanka is extremely restricted.

A faint light in this regard was shed by Jayawardena J. in the Chunnakam Power Plant Case (2019) where the judge expressed no hesitation in being bound by the principles recognized in international environmental instruments (p. 49). Therefore, it can be expected that this judicial commitment retrieved in the Chunnakam Case will one day lead towards 
the judiciary enforcing the environmental rights recognized in international instruments in the domestic context of Sri Lanka. Nonetheless, until this broader approach is upheld clearly and specifically, one cannot entirely ignore the restricted approach adopted in the Singarasa Case with regard to the domestic enforcement of rights recognized in international legal instruments, including environmental instruments.

\section{The Role of Public Interest Litigation in Defending the Environment in Sri Lanka}

In analyzing the efficacy of the existing body of human rights in Sri Lanka to fight against industrial water pollution, it is vital to examine the developments taking place with regard to the rules of standing and how they affect the ability to invoke fundamental rights against harmful industrial wastewater management practices. The judiciary in Sri Lanka originally recognized the standing of the related parties to petition court, especially in instances when the person whose rights are affected was incarcerated or dead (Goonetilleke, 2014). This approach was adopted in the cases, Somawathie v Weerasinghe (1990), Sriyani Silva v Iddamalgoda, OIC, Police Station Payagala and others (2003) and Lamahewage Lal v Officer in Charge, Minor Offences, Seeduwa Police Station (2005).

An important development in this regard is the ability of third parties to bring actions on a wide variety of matters on the basis that it affects their rights and the rights of the public at large (Goonetilleke, 2014). It is through this expanded standing that most of the environmental rights cases came before the court. In the Eppawela Case (2000) it was held in very clear terms that:

The petitioners ... are not disqualified because it so happens that their rights are linked to the collective rights of the citizenry of Sri Lanka ... Moreover, in the circumstances of the instant case, such collective rights provide the context in which the alleged infringement or imminent infringement of the petitioners' fundamental rights ought to be considered. (p. 244)

Similarly, in the Galle Face Green Case (2005), the court recognized the standing of the corporate bodies incorporated in Sri Lanka for the purpose of fundamental rights jurisdiction. Further the Rules of the Supreme Court have broadened the provisions of Article 126 to include "epistolary jurisdiction". According to Rajepakse (2009):

Under these Rules, when any alleged infringement or imminent infringement of a fundamental right is brought to the notice of the Supreme Court in writing, whether by the complainant or some other person, the Court may, in its discretion, treat such writing as a petition under Article 126(2), if satisfied that the affected person does not, or may not, have the means to pursue such a complaint in accordance with prescribed procedure. and that such a person has suffered or may suffer prejudice as a result of such infringement or imminent infringement. (p. 101)

This expanded standing, on the one hand, demands no coordination among the victims as any individual irrespective of his/her standing in the case can move the court (Schafer, 2000). On the other hand, it prevents the likelihood that certain individuals may never enforce their rights against water pollution due to lack of funds, knowledge, or fear of victimization. 
Further, the Supreme Court has allowed different organizations to intervene in fundamental rights cases filed by private parties as amicus curiae. For instance, in the Noise Pollution Case (2007) which involved a dispute between two groups wanting to use loudspeakers, the Environmental Foundation Limited which was not a party to this case was permitted to intervene as amicus curiae on behalf of the public. Amicus curiae is significant for fundamental rights cases involving industrial wastewater failures since it allows non-procedural parties of a case full access to a court of law to provide legal reasoning in support of effective judicial protection against such failure. It has enormous potential to channel and catalyze public participation against polluting industrial activities.

\section{Suggestions for Law Reform}

The above discussion clearly elaborates the necessity of expanding the scope of fundamental rights in Sri Lanka to provide reasonable safeguards against industrial water pollution and its long-lasting negative impacts. The main reform in this regard would be the incorporation of the right to environment into the fundamental rights chapter of the Constitution. This will help Sri Lanka to be in line with internationally accepted human and environmental rights standards and to be one of the few countries in the world which has an express right to environment.

In adopting the right to environment, it is important not to resort to an extreme anthropocentric view which focuses on environmental damage affecting human beings rather than the environment itself. The right to environment should consider humans as part of the environment rather than the central concern of environmental decision making. The right should not always be interpreted relative to human beings but should, rather, recognize the inter-woven relationship between and among every component of nature and should take a more holistic approach that harm caused to one single constituent of the environment will have adverse ripple effects on the environment as a whole (Konasinghe, 2019). In this regard, Sri Lanka can even deviate from the narrow concept of the right to environment and recognize the legal rights and personhood of nature. Through such recognition, Sri Lanka can ensure that the inherent and intrinsic values of nature are protected against industrial water pollution. The best method of recognizing the rights of nature will be through the Constitution, as is in Ecuador, because constitutional guarantees cannot be dispensed with according to the discretion of the decision makers. The right to environment will, at the same time, recognize the duties of the bearers of the right towards the environment. Therefore, the definition of the right to environment will be more aligned with the approach adopted in the Stockholm Declaration which acknowledges the right of human beings to an environment that permits a life of dignity and well-being, while imposing upon them a duty to protect it for the sake of present and future generations.

Secondly, Sri Lanka should include the right to life explicitly in its Constitution following the example set by India. Whatever objective the drafters had when omitting this most fundamental and crucial right, perhaps with the idea that it is already implicit in the Constitution and that the express recognition of such right will only limit its scope for progressive interpretation, has not been successfully achieved in the forty years following 
the enactment of the Constitution. If anything, the judiciary has shrunk the scope of the right to life to mean "mere existence". It is undisputed that its scope should go beyond mere existence and that people should have the ability to invoke the right to life when the quality of their life is degraded due to improper wastewater discharges.

Thirdly, the recognition of the right to water, which ensures the right of the common citizenry to enjoy non-contaminated water, and the right to health, which provides a shield against health hazards arising out of environmental pollution triggered by industrial wastewater, can also form a progressive step towards conferring better legal protection against industrial water pollution. In recognizing these two rights, Sri Lanka can either insert two separate rights into the Constitution on water and health, or leave room for the judiciary to incorporate them within the scope of the right to environment and life as it is done in India. Even though the right to water has not yet been recognized as a stand-alone right in international instruments, this does not underrate the significance of this crucial right, or bar Sri Lanka from recognizing it as a separate right. While international standards are constantly being used by judges and others to shape domestic law and policy, domestic activism can also influence the development of international norms.

The enforceability of fundamental rights should also be expanded. The constitutional remedy for the enforcement of fundamental rights is restricted to administrative or executive actions in terms of Articles 17 and 126 (Constitution of Sri Lanka, 1978), and they can be enforced neither against judicial actions nor against private parties. The term executive or administrative action in Article 17 and Article 126 of the Constitution should be replaced with the term State action. State action covers violations of fundamental rights by all three organs of the government: executive, legislature, and judiciary, and deviates from the very narrow approach adopted in Sri Lanka with regard to the enforcement of fundamental rights. The term State action should be interpreted to cover all forms of State actions which are done "under the colour of the State law", and any person who exercizes power possessed by virtue of State law shall come within the purview of the State and be challenged as State action (Abeysekara, 2010). While the role of public law, specifically fundamental rights, is to provide legal safeguards against the arbitrary exercise of executive and administrative power, Sri Lanka has recognized private entities exercizing powers affecting the public as being subjects of public law. On a similar premise, Sri Lanka can bring private entities improperly discharging wastewater and acting contrary to the interests of the general public into the ambit of public law. Where the most crucial rights of the people are infringed, they should be vindicated regardless of whether the violator is a part of the executive and administrative body or not.

Moreover, Sri Lanka should deviate from the extreme dualistic approach, at least as far as the crucial rights to life and environment are concerned. It has been internationally accepted that the underlying rationale for dualist theory is no longer valid vis-à-vis human rights and there is growing support for human rights treaties to enjoy a special status (Dias \& Gamble, 2006). The judiciary should be willing to recognize this special status of human rights in international law over its commitment to be bound by the dualist theory which is not even clearly reflected in the constitutional framework in Sri Lanka. On the other 
hand, environmental rights and principles are constantly evolving in the international arena and the best and most convenient approach of adopting international environmental law developments would be to directly apply them in the domestic context to the extent it does not seriously conflict with the domestic laws.

\section{Conclusion}

The rights embodied in the Constitution of Sri Lanka are not adequate to defend the environment and human beings against the adverse impact of industrial water pollution. The absence of the right to life, environment, health, and water in the Constitution has been exacerbated by the unwillingness on the part of the judiciary to be bound by international obligations undertaken by the State of Sri Lanka and restrictions in the enforceability of fundamental rights. Any attempt to embrace the emerging legal trend of the recognition of rights of nature for the protection of water resources is entirely non-existent in Sri Lanka. Therefore, it is essential for Sri Lanka to amend the fundamental rights chapter in the Constitution as well as the judicial attitude towards internationally recognized human rights while enhancing the judicial role in environmental litigation to protect the environment. Through such an approach, Sri Lanka will be able to ensure the maximum protection of the rights of the people and the environment against industrial water pollution, while ensuring that it plays its part in the collective global effort towards the protection and conservation of nature for the sake of present and future generations and the achievement of sustainable development.

\section{References}

Abeysekara, T. B. (2010). The need to expand Sri Lanka's fundamental rights jurisdiction: A comparative analysis of the USA, India, and Trinidad and Tobago. Sri Lanka Journal of International Law, 22(1), 59-88.

Additional Protocol to the American Convention on Human Rights in the Area of Economic, Social and Cultural Rights (Protocol of San Salvador), OAS Treaty Series No. 69, 1988, November 17.

African Charter on Human and Peoples' Rights, 1981, June 27, 21 ILM 58.

Agenda 21, Report of the United Nations Conference on Environment and Development 1992, June 3 - 14, A/CONF.151/26/Rev.1 Vol. I and Vol. I/Corr.1, Vol. II, Vol. III and Vol. III/Corr.1

American Convention on Human Rights, 1969, November 22.

Boyle, A. (2006). Human rights or environmental rights? A reassessment. Fordham Environmental Law Review, 18(3), 471-551.

Constitution of Ecuador. (2008).

Constitution of India. (1950).

Constitution of the Democratic Socialist Republic of Sri Lanka. (1978). 
Cooney, J. F., Tran, M., \& Sjostrom, K. (2012). Know your rights: A guide to the United States Constitution. United States Attorney's Office, District of Minnesota.

Declaration of the United Nations Conference on Environment and Development (Rio Declaration), 1992, August 12, A/CONF 151/26.

Declaration of the United Nations Conference on the Human Environment (Stockholm Declaration), 1972, June 16, A/CONF.48/C.9.

Dias, N. \& Gamble, R. (2006). Nallaratnam Singarasa v Attorney General: The Supreme Court of Sri Lanka confirms limited human rights protection for Sri Lankan citizens. Sri Lanka Journal of International Law, 18(2), 445-458.

Donnelly, J. (2003). Brave new brain: Conquering mental illness in the era of the genome, Oxford University Press.

Edmundson, W. A. (2004). An introduction to rights. Cambridge University Press.

Environmental Foundation Limited. (2015). Industrial responsibilities towards the environment. Environmental Foundation Limited.

European Convention on Human Rights, 1953, September 3.

Falkenmark, M., (1977). UN water conference: Agreement on goals and action plan. Ambio, 6(4), 222-227.

Fernando, M. (2004). Victor Ivan v Sri Lanka - Decision: Its impact on human rights. Sri Lanka Journal of International Law, 16, 289-296.

Framework Law of Mother Earth and Integral Development for Living Well (Ley Marco de la Madre Tierra y Desarrollo Integral para Vivir Bien) 2012 (Bolivia).

Gellers, J. C. \& Jeffords, C. (2019). Environmental rights in the Asia Pacific region: taking stock and assessing impacts. Asia Pacific Journal of Environmental Law, 22(2), 190-206. https://doi. org/10.4337/apjel.2019.02.01

Goonetilleke, R. (2014). Public interest litigation: A species of direct democracy and good governance. Sri Lanka Journal of Development Administration, 4, 83-96. http://doi.org/10.4038/ sljda.v4i0.7116

Guissé, E. H. (2002). Report on the relationship between the enjoyment of economic, social and cultural rights and the promotion of the realization of the right to drinking water supply and sanitation [E/CN.4/Sub.2/2002/10]. UN Economic and Social Council.

Hachten, W. A. (2005). The troubles of journalism: A critical look at what's right and wrong with the press. Lawrence Erlbaum Associates Publishers.

International Covenant on Civil and Political Rights, 1966, December 16, UNTS 171.

International Covenant on Economic, Social and Cultural Rights, 1976, December 16, UNTS 993.

International Law Association. (2004). Berlin Rules on Water Resources. 
Jayasumana, C., Orantes, C., Herrera, R., Almaguer, M., Lopez, L., Silva, L. C., Ordunez, P., Siribaddana, S., Gunatilake, S., \& De Broe, M. E. (2017). Chronic interstitial nephritis in agricultural communities: a worldwide epidemic with social, occupational and environmental determinants. Nephrology Dialysis Transplantation, 32(2), 234-241. https://doi.org/10.1093/ndt/ gfw346

Jayawickrama, N. (2016). The Right to Information bill - A legislative and judicial misadventure. Bar Association Law Journal, XXII (Law Asia Special Commemorative Issue), 127-138.

Jeevaratnam, V., Balakumar, S., Mikunthan, T., \& Prabaharan, M. (2018). Quality of groundwater in Valikamam area, Jaffna Peninsula, Sri Lanka. International Journal of Water Resources and Environmental Engineering, 10(2), 09-16. https://doi.org/10.5897/IJWREE2017.0714

Kafle, K., Balasubramanya, S., \& Horbulyk, T. (2019). Prevalence of chronic kidney disease in Sri Lanka: A profile of affected districts reliant on groundwater. Science of the Total Environment, 694, Article 133767. https://doi.org/10.1016/j.scitotenv.2019.133767

Konasinghe, K. (2019). Assuring health and wellbeing beyond the mankind: Legal proposition to move from anthropocentric approach to right to health to a right to health inclusive of nature itself. Annual Research Symposium, University of Colombo, Colombo, Sri Lanka.

Law of Mother Earth (Ley de Derechos de La Madre Tierra) 2010 (Bolivia)

Leelakrishnan, P. (2010). Environmental Law in India (3rd edition). Butterworth.

Leib, L. H. (2011). An overview of the characteristics and controversies of human rights. Brill.

Mwanza, R. M. (2019). Harnessing the transformative potential of the constitutional human right to a clean and healthy environment in the context of corporate environmental damage in Kenya: A critical perspective. Journal of Human Rights and the Environment, 10(2), 215-238. https://doi. org/10.4337/jhre.2019.02.04

Perera, H. (2015, June 01). Conflict analysis: Case study of Weliveriya - Rathupaswala, Sri Lanka water crisis. Conflicts Transformers. https://conflictstransformers.wordpress.com/2015/06/22/ conflict-analysiscase-study-of-weliveriya-rathupaswala-sri-lanka-water-crisis/

Rajepakse, R. (2009). How environmental cases come before the courts. In M. Gomez (Ed), Judges on Environmental Law (pp. 99-125). UNEP.

Rodrigo, M. (2013, August 12). Who pollutes Rathupaswala water? Window to Nature. https:// window2nature.wordpress.com/2013/08/12/who-pollutes-rathupaswala-water/

Schafer, H. B. (2000). The bundling of similar interest in litigation: The incentives for class action and legal actions taken by associations. European Journal of Law and Economics, 9, 183-213.

Shelton, D. L. (1992) What happened in Rio to human rights? Yearbook of International Environmental Law,3(1), 75-93. https://doi.org/10.1093/yiel/3.1.75

Shelton, D. L. (2002). Human rights, health and environmental protection: Linkages in law and practice. (WHO Health and Human Rights Working Paper Series No. 1). https://www.who.int/ hhr/Series_1\%20\%20Sheltonpaper_rev1.pdf?ua=1 
Shelton, D. L. (2010). Human rights and the environment: Substantive rights. In M. Fitzmaurice, D. M. Ong, \& P. Merkouris (Eds.), Research handbook on international environmental law (pp. 265-283). Edward Elgar Publishing Limited.

Suntha, S. (2018). Oil spill contamination of groundwater in Chunnakam aquifer, Jaffna, Sri Lanka. Open Water Journal, 5(2), 24-29.

Te Awa Tupua (Whanganui River Claims Settlement) Act 2017 (New Zealand)

Te Urewera Act 2014 (New Zealand)

United Nations Committee on Economic, Social and Cultural Rights General Comment No. 14, 2000, August 11, UN Doc. E/C.12/2000/4.

United Nations Committee on Economic, Social and Cultural Rights General Comment No. 15, 2003, January 20, UN Doc. E/C.12/2002/11.

United Nations. (2010). The right to water: Fact Sheet 35.

United Nations Convention on the Rights of the Child, 1989, November 30.

United Nations General Assembly Resolution, 1990, December 14, 45/94.

United Nations General Assembly Resolution, 2010, July 28, A/RES/64/292.

United Nations Human Rights Council General Comment No. 6, 1982, April 30.

Universal Declaration of Human Rights, 1948, December 10, 217 A (III).

Vallipuranathan, M. (2015, April 27). Science, politics \& manipulations of water pollution in Jaffna. Colombo Telegraph. https://www.colombotelegraph.com/index.php/science-politicsmanipulations-of-water-pollution-in-jaffna/

Van der Linde, M. \& Louw, L. (2003) Considering the interpretation and implementation of article 24 of the African Charter on Human and Peoples' Rights in light of the SERAC communication. African Human Rights Law Journal, 3(1), 167-187.

Vasak, K. (1982). The international dimensions of human rights. Greenwood Press.

White, H. (2018). Indigenous peoples, the indigenous trend toward legal personhood for nature, and the United States. American Indian Law Review, 43(1), 129-165.

Wickramasinghe, B. (2015). Right to Information and sustainable development: A development agenda for Sri Lanka. 8th International Research Conference, Kotelawala Defence University, Ratmalana, Sri Lanka.

\section{List of Cases}

Adhikari and another v Amarasinghe and others, Application No.251/2002 (SC., 2002).

Al Haj MTM Ashik v RPS Bandula, OIC Weligama (the Noise Pollution case), FR Application No. 38/2005 (SC., 2007). 
Andra Pradesh Pollution Control Board v MV Nayadu, AIR SC 812 (SC., 1999).

Bulankulama v Secretary, Ministry of Industrial Development (Eppawela Case) 3 Sri LR 243 (SC., 2000).

Chhetriya Pardushan Mukti Sangarsh Samati v State of Uttar Pradesh, AIR SC 2060 (SC., 1990).

Deshan Harindra (a minor) v Ceylon Electricity Board, 5 (4) SAELR 116 (SC., 1998).

Environmental Foundation Limited v Attorney General (Nawimana Case), SC Application No. 128/91 (SC., 1992).

Environmental Foundation Limited v Urban Development Authority (Galle Face Green Case), FR Application No. 47/2004 (SC., 2005).

FK Hussain v Union of India, AIR Ker 321 (HC. Ker 1990).

Gunaratne v Homagama Pradeshiya Sabha, 2 Sri LR 11 (SC., 1998).

Heather Therese Mundy v The Central Environmental Authority, Appeal 58/2003 (SC., 2004).

Indian Council for Enviro-legal Action v Union of India (Sludge Case), AIR SC 1446 (SC., 1996).

Jayawardena v Akmeemana Pradeshiya Sabha and others, Application No. 594/96/FR (SC., 1997).

KM Chinnappa v Union of India, AIR SC 724 (SC., 2003)

Lalit Miglani v State of Uttarakhand and others, No.140 of 2015 (HC U'chal 2017).

Lamahewage Lal v Officer in Charge, Minor Offences, Seeduwa Police Station 1 Sri LR (SC., 2005).

MC Mehta v Union of India, AIR 982 (SC., 1987a).

MC Mehta v Union of India, AIR 1086 (SC., 1987b).

MC Mehta v Union of India, AIR 1037 (SC., 1988a).

MC Mehta v Union of India, AIR 1115 (SC., 1988b).

MC Mehta v Kamal Nath, AIR 1997 (SC., 2000).

Mohd Salim v State of Uttarakhand and others, No.126 of 2014 (HC U'chal., 2017).

Nallaratnam Singarasa v Attorney General, Spl (LA) No. 182/99 (SC., 2006).

Oneryildiz v Turkey, (2004) EHRR 41.

Premachandra v Major Montague Jayawickrema and Others, 2 Sri LR 90 (SC., 1994).

Rathnayake Tharanga Lakmali v Officer-in-Charge, Crime Branch, Embilipitiya Police Station SC/ FR Application 577/2010 (SC., 2019).

Ravindra Gunawardena Kariyawasam v Central Environmental Authority and others (Chunnakam Power Plant Case), FR Application No. 141/2015 (SC., 2019)

Rural Litigation and Entitlement Kendra v State of Uttar Pradesh (Dehradun Quarrying Case) AIR 652 (SC., 1985). 
Sirisena Cooray v Tissa Bandaranayake, 1 Sri LR 1 (SC., 1999)

SK Garg v State of Uttar Pradesh, AIR All 41 (HC. All, 1999).

Somawathie v Weerasinghe 2 Sri LR (SC., 1990).

Sriyani Silva v Iddamalgoda, OIC, Police Station Payagala and others, No. 471/2000 (FR) (SC., 2003).

Subhash Kumar v State of Bihar, AIR 420 (SC., 1991).

Sugathapala Mendis v Chandrika Bandaranaike Kumaratunga (Waters Edge Case), FR Application 352/2007 (SC., 2008).

The State of Uttarakhand v Mohd Salim, SLP (C) No. 16879/2017 (SC., 2018).

Watte Gedara Wijebanda v Conservator General of Forest and eight others, FR Application 118/2004 (SC., 2007).

Weerawansa v Attorney General, Application No. 730/96 (SC., 2000). 